цінностей та норм. Дозвілля забезпечує необхідні умови для творчості, просвітництва, відпочинку, без яких стає неможливим формування повноцінної особистості [4].

Отже, педагогіка дозвілля охоплює різноманітні теоретикопрактичні проблеми: осмислення процесів становлення і розвитку духовної культури особистості, залучення людини до загальносвітових цінностей у вільний від основних занять час; вибір інструментарію людинознавчих технологій дозвіллєвої практики на основі прийнятих в суспільстві культурних зразків i етичних норм, що регулюють соціальну поведінку людини та спрямовані на включення переживання як способу пізнання самого себе i світу; визначення сутності продуктивної дозвільної діяльності різних вікових категорій населення; виховання культури і світоглядного самовизначення особистості.

\title{
Література:
}

1. Воловик А. Ф., Воловик В. А. Педагогика досуга : учебник. Москва : Флинта, 1998. 232 с.

2. Крестьянов В.П. Педагогика досуга. Орел: ОГУ, 2010. 156 с.

3. Шарковская Н.В. Педагогика досуга в контексте современного гуманитарного знания. Культура и образование. 2018. № 4 (31). C. 13-21.

4. Цимбалюк Н.М. Дозвілля в Україні: теоретичні та емпіричні аспекти : монографія. Київ : ДАКККіМ, 2003. 224 с.

DOI https://doi.org/10.30525/978-9934-26-114-5-23

\section{КОНТРОЛЬНІ ТЕСТИ ЯК КОМПОНЕНТ КОНТРОЛЬНО- ОЦІНЮВАЛЬНОЇ ДІЯЛЬНОСТІ В ГІМНАЗЇ̈ (НА ПРИКЛАДІ ГУМАНІТАРНОГО ПРОФІЛЮ)}

\section{Рогова В. Б.}

здобувач відділу управління та економіки загальної середньої освіти Інститут педагогіки НАПН України м. Київ, Україна

Дидактичний тест як компонент контрольно-оцінювальної діяльності в гімназії уможливлює об'єктивне вимірювання навчальних досягнень здобувачів освіти, подальше корегування процесу учіння, управління навчально-пізнавальною діяльністю, моделювання подальшої освітньої траєкторії. 
Дидактичний тест забезпечує уналежнене цілеспрямоване, однакове для всіх випробовуваних діагностування, об'єктивне вимірювання навчальних досягнень здобувачів освіти на рівні предметних компетентностей. Подібна підсумкова робота дозволяє встановити зв'язки між запроектованими стандартом, реалізованими у процесі освітнього процесу, реальними навчальними досягненнями і відповідними кількісно-калітативними результатами. Варто наголосити на тому, що запитання у структурі дидактичного тесту необхідно враховувати зміст навчального предмета, формулювання питань до тестового завдання, які б передбачали не лише застосування досвіду навчальної діяльності, але формовані в межах навчального предмета загальнопредметні вміння.

Дидактичні тести є аналогом стандартизованого тесту, який учні гімназії складають після вивчення навчального предмета (у рамках гуманітарного напряму, як приклад, репрезентуємо дидактичний тест «Українська мова»), зміст якого відтворено в Освітньому стандарті. Однією із властивостей пропонованих стандартизованих тестів 3 української мови / літератури / зарубіжної літератури $є$ його: иілісність (склад тесту співвідноситься з інтегрованою якістю тестових завдань); об'єктивність вимірювання рівня навчальних досягнень (оскільки тестове завдання $є$ структурним компонентом дидактичного тесту, тестове завдання відповідає гомогенним вимогам, тобто однотипним, як за змістом, так і за складністю виконання (у межах кількісного оцінювання).

Конструювання дидактичного тесту відповідно до вимог специфікації передбачає врахування завдань тестування 3 навчального предмета (як приклад, 3 української мови); вимог, які стосуються кількості і типу використовуваних завдань; структури тесту (містить послідовність дій (алгоритми та інструкції; теоретичну довідку), формулювання завдання до тесту спрямоване на виявлення сформованості ключових компетентностей (мовної і мовленнєвої, комунікативної, соціокультурної компетентностей у процесі вивчення української мови, розділу Синтаксис).

Прикладом може слугувати тестування 3 розділу «Синтаксис» (Українська мова), який передбачає відповідно до рівня підготовки учнів надавати завдання відповідної складності, адаптовані до індивідуального рівня знань, побудовані з урахуванням принципів (комунікативно-мовленнєвого спрямування; урахування особливостей рідної (украӥнської) мови визначальної ролі вправ і тестових завдань (розвиток мовленнєвих умінь корелює зі створенням типових мовленнєвих стереотипів; методично правильно дібраний дидактичний 
матеріал моделює процес навчання мови / літератури як комунікативний, результативний відповідно до моделювання академічного дискурсу).

Дидактичний тест мовленнєвого / літературознавчого спрямування за своєю специфікацією передбачає роботу з текстовими фрагментами (формально-граматичний, аксіологічний критерії відбору) сприяє виробленню не лише ключових компетентностей (наприклад, зміст тестів із синтаксису української мови спрямований на діагностування рівня сформованості мовної і мовленнєвої компетентності учнів) i у який спосіб (структурно-семантичні, функціональні, граматичні характеристики речення), але також активної комунікативної позиції учнів гімназії, що репрезентується у відкритих відповідях (Прокоментувати... Продовжити думку).

Ураховуючи те, що статичні варіанти відповідей дидактичного тесту значною мірою обмежують творчий розв'язок, варіативне подання свого рішення (своєї думки) про те чи те завдання, завдання розробленого дидактичного тесту рекомендовано подавати по одному, залежно від успішності відповіді здобувача освіти на попередній тест (адаптивність таких тестів полягає в тому, що здобувачу освіти пропонується тест більш чи менш складний за розв'язком залежно від динаміки: якщо учень на контрольному етапі не демонструє вміння застосовувати алгоритм, пропонується менш складний тест, який передбачає однотипну відповідь; якщо учень демонструє вміння застосовувати алгоритми, пропонувати варіативний розв'язок, наступний тест передбачає розгорнуту відповідь, що моделює текст (композиція і тематична відповідність корелює з валідністю відкритого типу питання).

Рух ускладнення чи спрощення під час діагностування навчальних досягнень у змісті навчального предмета «Українська мова» може бути таким:

1. Класифікаиія об'єктів дослідження - односкладних речень.

У якому рядку подано односкладне (називне, означено-особове, неозначено-особове, узагальнено-особове, безособове речення?

Знайдіть у пропонованому тексті вказані синтаксичні одиниці:

Текст 4. Така прозорість! (1) Віч не відвести (2).

У світі-ти (3). І світ ией - через тебе (4).

І тільки думи ходять без потреби (5).

Як ті вітри, щуо маџають хрести (6) [Лютий Г. Вибране : вірші, поеми, пісні. Запоріжжя, 1999. 568 с., с. 80].

А) просте односкладне (інфінітивне) речення, поширене, повне, неускладнене. 
Б) просте двоскладне речення, поширене, повне, неускладнене.

В) просте односкладне (номінативне) речення, поширене, повне, неускладнене.

2. Формально-граматичні характеристики односкладних речень. У якому рядку подано односкладне (означено-особове - тип речення) речення 3 головним членом, вираженим дієсловом першої особи однини дійсного способу, теперішнього часу.

3. Встановіть відповідність між типом простого речення i прикладом такого речення.

4. Переструктуруйте речення так, щоб отримати просте ускладнене; складнопідрядне означальне...

5. Розгорніть думку, використовуючи прості ускладнення речення (поширені однорідними членами речення).

3 огляду на те, що дидактичні тести є гомогенними, становлять змістовно однорідні завдання, реалізують функції навчання, самоконтролю, саморегуляції й самокорекції, контрольне тестування можна проводити після вивчення теми; розділу (Наприклад, Односкладні речення дієслівного типу. Односкладні речення іменникового типу. Синтаксис української мови); здійснити семестрове діагностування, яке дозволяє на основі зіставлення даних про рівень навчальних досягнень на початку семестру визначити подальші тенденції в навчанні, застосувати корегувальні техніки у випадку неуспішності, незасвоєння тих чи тих блоків знань у змісті навчального предмета).

Дидактичний тест має передбачати алгоритми розв'язку, де, 3 організаційного боку, ідеться інструкцію розуміння завдання i заповнення таблиці; зі змістового, - володіння категорійно-поняттєвим апаратом (задля успішного розв'язання розділу «Синтаксис української мови» термінологічна довідка має передбачати: визначення речення як синтаксичної одиниці; зразок дієвідмінювання (у структурі речення морфологічне вираження присудка як складника граматичної основи); класифікація речень).

Використання тестування як засобу контролю за навчальним процесом з української мови сприяє активізації навчально-пізнавальної діяльності учнів, а також їх самовдосконаленню.

Використання дидактичних тестів дозволяють отримати показники на основі: 1) кінцевих результатів упровадження контрольно-оцінної системи до навчального процесу (передбачає застосування педагогічних інновацій); 2) раціональності організаційної структури навчального процесу з використанням контрольно-оцінної системи на основі застосування дидактичних тестів; 3) управління якістю навчання 
в закладі освіти (гімназії) на основі диференціації й індивідуалізації під час роботи зі здобувачами освіти.

Компетентнісно-орієнтований підхід до навчального процесу в умовах гімназії орієнтує на розроблення й системне застосування дидактичних тестів із навчального предмета. Гуманітарний профіль передбачає дотримання відповідних характеристик тестів (мовний матеріал класифікується, аналізується 3 позиції формально-граматичних і структурно-семантичних характеристик; мовний матеріал добирається із творів художньої літератури, що сприяє виробленню естетичного смаку учнів, а також сприяє виробленню комунікативностилістичних якостей мовлення). Оскільки в умовах гімназії навчання здійснюється за профілями, дидактичні тести мають специфікацію, передбачають високий творчий рівень здобувачів освіти під час розв'язання таких тестів, відповідно, сприяють формуванню мовної особистості учнів гімназії, інтенсифікують розвиток фахового мислення майбутніх спеціалістів, Активізація освітньої, розвивальної й мотиваційної функцій контрольних тестів як компонента контрольнооцінювальної діяльності в гімназії відбувається з урахуванням моделювання освітньої траєкторії здобувачів освіти, що передбачає гнучке застосування дидактичних тестів з урахуванням складності завдань / iз розподілом завдань за рівнем засвоєння навчального матеріалу.

\title{
Література:
}

1. Булах I. Є., Мруга М. Р. Створюємо якісний тест : навчальний посібник. Київ : Майстер-клас, 2006. 160 с.

DOI https://doi.org/10.30525/978-9934-26-114-5-24

\section{ЗМІСТ ТОЛЕРАНТНОСТІ ОСОБИСТОСТІ ВІЙСЬКОВОСЛУЖБОВЦЯ НАЦІОНАЛЬНОЇ ГВАРДІЇ УКАЇНИ}

\author{
Тробюк Н. Ю. \\ викладач кафедри психології та педагогіки \\ Наџіональна академія Начіональної гвардї України \\ м. Харків, Україна
}

Декларація принципів толерантності [1] наголошує про особливу важливість толерантності в сучасному світі, про ії глобальний характер, необхідність формування атмосфери толерантності у взаєминах, 